\title{
Cord around the neck syndrome
}

\author{
Morarji Peesay \\ From Stillbirth Summit 2011 \\ Minneapolis, MN, USA. 6-8 October 2011
}

A nuchal cord (or Cord-Around-the Neck (CAN)) occurs when the umbilical cord becomes wrapped around the fetal neck 360 degrees. Nuchal cords are very common, the incidence of nuchal cord increases with advancing gestation from $12 \%$ at 24 to 26 weeks to $37 \%$ at term [1]. Most are not associated with perinatal morbidity and mortality. In some fetuses and newborns CAN may cause problems, especially when the cord is tightly wrapped around the neck. The cluster of cardiorespiratory and neurological signs and symptoms associated with unique physical features that occur secondary to tight cordround-the-neck has been referred to as 'tCAN syndrome' (tight Cord Around the Neck Syndrome) [2]. A small number of studies have shown that nuchal cord and or tCAN can affect the outcome of delivery and may have long-term effects on the infant [3] and but as a causative factor for stillbirth it is debatable $[4,5]$. However, some case reports of postmortem findings on stillbirths show negative pathology reports and tight cord around the neck being the only cause of death [6].

It is the unique physical features of tCAN syndrome that distinguishes it from birth asphyxia even though there are many similarities between these two conditions. Umbilical cord abnormalities are considered as one of the causative factor for birth asphyxia. The manifestation of tCAN symptomatology seems to happen both in the presence of normal and depressed AGPAR scores [7]. Umbilical cord compression due to tCAN may cause obstruction of blood flow first in thin walled umbilical vein, while infant's blood continues to be pumped out of baby through the thicker walled umbilical arteries thus causing hypovolemia and hypotension resulting in acidosis [8]. Anemia [9] and mild respiratory distress may occur. Some of these infants may also have facial and conjuctival petechiae [10] and rarely petechiae of the neck and upper part of the chest and skin abrasion of

Correspondence: peesay@yahoo.com

Montgomery General Hospital/Georgetown University Hospital, Washington DC, USA neck [11] where the cord was tightly wrapped and facial suffusion [12], all of which can also be seen in some postmortem findings of stillbirth infants who had tCAN [Archana Bargaje, personal communication]. If born alive, some of these infants may also be somewhat obtunded with a low tone and have transient feeding difficulties. These findings raise the possibility of transient encephalopathy, which may lead to long-term complications.

A stillbirth attributed to a cord problem should have evidence of cord obstruction or circulatory compromise. Other potential causes of stillbirth need to be excluded prior to labelling cord abnormalities as the causative factor, since cord abnormalities seen in more than a third of all normal live births.

The tCAN Syndrome may conceptually be similar to strangulation which may result in non lethal problems or death. The pathophysiological mechanisms of strangulation injuries (lethal and non lethal) involves venous, arterial obstruction (arterial spasm due to carotid pressure) in the neck and vagal collapse (increased parasympathetic tone) [13]. This can lead to cerebral stagnation, hypoxia, and unconsciousness, which, in turn, produces loss of muscle tone. The same pathophysiology of strangulation may possibly be applicable to tCAN syndrome in neonates. A study on potentially asphyxiating conditions and spastic cerebral palsy in infants of normal birth weight showed evidence of association of tCAN in children with quadriplegia [14].

Intermittent umbilical cord occlusion in preterm and near term sheep caused a decline in $\mathrm{pO}_{2}$ and $\mathrm{pH}$, and higher $\mathrm{PCO}_{2}$ and altered brain protein synthesis/degradation [6]. Whether human fetal intermittent strangulation by tCAN have similar brain protein alterations and thus long-term effects remains to be seen. Using specific placental histologic criteria for umbilical blood flow restriction in unexplained stillbirth Parast et al [4] showed significant correlation of placental changes of "minimal histologic criteria" with cord accidents (as tCAN is part 
of cord accidents). Nuchal cords showed highest rates of thrombosis-related placental histopathology and fetal thrombotic vasculopathy and thrombosis seems to be highly specific for cord related stillbirths $[4,5]$.

\section{Published: 28 August 2012}

\section{References}

1. Clapp JF, Stepanchak W, Hashimoto K, Ehrenberg H, Lopez B: The natural history of antenatal nuchal cords. Am J Obstet Gynecol 2003, 189:488-493.

2. Peesay M, Mehta Nitin: Cord Around the Neck Syndrome. 2011, 6(2):11-12 [http://www.neonatologytoday.net/newsletters/nt-feb11.pdf], (accessed 12/29/2011).

3. Clapp JF, Lopez B, Simonean S: Nuchal cord and neurodevelopmental performance at 1 year. J Soc Gynecol Investig 1999, 6(5):268-72.

4. Parast MM, Crum CP, Boyd TK: Placental histologic criteria for umbilical blood flow restriction in unexplained stillbirth. Human Pathology 2008, 39:948-953.

5. Tantbirojn P, Saleemuddin A, Sirois K, Crum CP, Boyd TK, Tworoger S, Parast MM: Gross abnormalities of the umbilical cord: related placental histology and clinical significance. Placenta 2009, 30(12):1083.

6. Rocha E, Totten S, Hammond R, Han V, Richardson B: Structural proteins during brain development in the preterm and near-term ovine fetus and the effect of intermittent umbilical cord occlusion. Am J Obstet Gynecol 2004, 191(2):497-506.

7. Martin GC, Green RS, Holzman IR: Acidosis in Newborns with Nuchal Cords and Normal Apgar Scores. Journal of Perinatology 2005, 25:162-165.

8. Vanhaesebrouck P, Vanneste K, de Praester C, Van Trappen Y, Thiery M: Tight nuchal cord and neonatal hypovolaemic shock. Arch Dis Child 1987, 62:1276-1277.

9. Shepherd AJ, Richardson CJ, Brown JP: Nuchal Cord as a Cause of Neonatal Anemia. Am J Dis Child 1985, 139(1):71-73.

10. Fletcher MA: Petechiae on face due to tight nuchal cord. Physical Diagnosis in Neonatology Lippincott- Raven; 1998.

11. Rudolph AJ: Nuchal Cord with Skin Abrasion Core Around the Neck. Atlas of the Newborn B.C Decker Inc; 1997.

12. Rudolph AJ: Suffusion of the face and head. Atlas of the Newborn B.C Decker Inc; 1997.

13. Stapczynski JS, Dietrich AM: Theories of Strangulation Injuries. Emergency Medicine Reports, A Practical Journal for Emergency Physicians; emreports.com 2010, 31(Number 17):195-6 [http://www.ahcmedia.com/public/samples/ emr.pdf], (accessed 12/29/2011).

14. Nelson KB, Grether JK: Potentially asphyxiating conditions and spastic cerebral palsy in infants of normal birth weight. Am J Obstet Gynecol 1998, 179:507-13.

doi:10.1186/1471-2393-12-S1-A6

Cite this article as: Peesay: Cord around the neck syndrome. BMC Pregnancy and Childbirth 2012 12(Suppl 1):A6.

\section{Submit your next manuscript to BioMed Central and take full advantage of:}

- Convenient online submission

- Thorough peer review

- No space constraints or color figure charges

- Immediate publication on acceptance

- Inclusion in PubMed, CAS, Scopus and Google Scholar

- Research which is freely available for redistribution

Submit your manuscript at www.biomedcentral.com/submit
Biomed Central 